\title{
Profil Keterampilan Memecahkan Konflik Interpersonal Siswa Berbakat Istimewa di SMA Kota Malang
}

\author{
Rosalia Dewi Nawantara \\ rosaliadewi11@unpkediri.ac.id \\ Program Studi Bimbingan dan Konseling \\ Fakultas Keguruan dan Ilmu Pendidikan \\ Universitas Nusantara PGRI Kediri
}

\begin{abstract}
Abstrak
Siswa berbakat istimewa memiliki karakteristik yang sangat khas, yaitu memiliki kecerdasan, komitmen tugas, dan kreativitas yang tinggi. Beberapa poin tersebut lantas menimbulkan pertanyaan tentang bagaimana keterampilan sosial mereka, khususnya mengenai keterampilan memecahkan konflik interpersonal. Seringkali kelebihan di bidang intelektual membuat anggapan bahwa social skill siswa berbakat istimewa kurang. Penelitian ini bertujuan untuk mengetahui profil keterampilan memecahkan konflik interpersonal siswa berbakat istimewa di SMAN Kota Malang. Pendekatan penelitian menggunakan pendekatan penelitian kuantitatif dengan teknik penelitian survei dan teknik total sampling. Sampel yang digunakan sebanyak 162 siswa. Instrumen penelitian menggunakan skala keterampilan memecahkan konflik interpersonal yang sudah teruji validitas dan reliabilitasnya. Hasil penelitian menunjukkan bahwa keterampilan memecahkan konflik interpersonal siswa berbakat istimewa di SMAN di Kota Malang terbanyak ada di kategori tinggi yaitu sebesar $76 \%$. Pada kategori sangat tinggi sebesar 22\%, kategori cukup sebesar 2\%, dan kategori rendah serta sangat rendah sebesar $0 \%$. Hasil penelitian ini dapat digunakan guru BK dalam merencanakan layanan BK pada siswa berbakat istimewa.
\end{abstract}

Kata kunci: keterampilan memecahkan konflik interpersonal, siswa berbakat Istimewa

\begin{abstract}
Gifted and talented students have very distinctive characteristics, namely having high intelligence, task commitment, and creativity. Some of these points then raise questions about how their social skills are, especially regarding interpersonal conflict solving skills. Often the advantages in the intellectual field make the assumption that the social skills of gifted and talented students are lacking. This study aims to determine the profile of interpersonal conflict solving skills of gifted and talented students at SMAN Kota Malang. The research approach used a quantitative research approach with survey research techniques and total sampling techniques. The sample used was 162 students. The research instrument used a scale of interpersonal conflict solving skills that had been tested for validity and reliability. The results showed that the most gifted and talented students' interpersonal conflict solving skills at SMAN in Malang were in the high category, namely $76 \%$. The very high category was $22 \%$, the moderate category was $2 \%$, and the low and very low category was $0 \%$. The results of this study can be used by counseling teachers in planning counseling services for gifted and talented students.
\end{abstract}

Keyword: interpersonal conflict resolution skills, gifted and talented students 
Jurnal PINUS: Jurnal Penelitian Inovasi Pembelajaran, 6 (2), 2021, Rosalia Dewi Nawantara

\section{PENDAHULUAN}

Konflik adalah hal yang seringkali muncul dalam interaksi hubungan interpersonal. Konflik merupakan ketidakseimbangan antara apa yang diharapkan dengan realita yang sebenarnya. Dalam sebuah hubungan interpersonal, konflik merupakan distorsi yang memerlukan keterampilan untuk memecahkannya.

Keterampilan memecahkan konflik interpersonal merupakan suatu kemampuan untuk memecahkan masalah antarpribadi atau interpersonal karena kepentingan dan struktur nilai yang berbeda satu sama lain (Nawantara, 2016).

Konflik yang muncul dalam hubungan interpersonal merupakan hal yang normal (Nawantara, 2017). Perbedaan berpendapat karena cara pandang yang juga berbeda pasti akan kerap ditemui dalam kehidupan bersosial. Akan tetapi tidak semua orang dapat menyelesaikan konflik tersebut dengan baik. Ada yang dapat menghadapi konflik tersebut secara konstruktif, ada juga yang tidak. Tawuran, main hakim sendiri, dan bahkan perkelahian yang berujung pada hilangnya nyawa juga terjadi karena ketidakmampuan individu untuk memecahkan konflik interpersonal.

Menurut (Johnson, 2009) terdapat lima strategi dasar untuk memecahkan konflik., yaitu (1) The Turtle (Withdrawing) cara menyelesaikan konflik dengan menghindari konflik tersebut dibanding menghadapinya (baik secara fisik maupun psikologis); (2) The Shark (Forcing) , cara menyelesaikan konflik dengan tindakan memaksa serta melawan; (3) The Teddy Bear (Smoothing), cara menyelesaikan konflik dengan lebih mementingkan hubungan daripada tujuan; (4) The Fox (Compromising), cara menyelesaikan konflik dengan melakukan kompromi; (5) The Owl (Confronting), cara menyelesaikan konflik dengan melihat konflik sebagai hal yang dapat dipecahkan dan dicari penyelesaiannya.

Selain beberapa strategi dasar menurut Johnson pada pembahasan bab sebelumnya, ada beberapa strategi menurut (Morton Deutsch, Peter T. Coleman, 2006), yaitu (1) Keterampilan membangun hubungan yang baik, merupakan suatu keterampilan untuk menciptakan suasana yang hangat saat beinteraksi dengan orang lain. Saat suasana terbangun dengan kondusif maka negosiasi akan suatu konflik dapat terwujud dengan baik; (2) Keterampilan memecahkan konflik secara kooperatif, merupakan inti dari bahasan sub bab ini. Sikap kooperatif atau cooperation dapat diuraikan dengan mendengarkan serta kemudian mengetahui keinginan orang lain; (3) Keterampilan dalam mengambil keputusan dan memecahkan masalah secara kreatif serta produktif. Sikap kreatif dan produktif juga dibutuhkan dalam memecahkan konflik dalam interaksi sosial. Kreatifitas dalam memimpin diskusi dalam rangka pemecahan masalah.

Siswa berbakat istimewa atau yang biasa dikenal dengan istilah gifted and talented children merupakan siswa yang masuk pada kategori Anak Berkebutuhan Khusus (ABK). 
Jurnal PINUS: Jurnal Penelitian Inovasi Pembelajaran, 6 (2), 2021, Rosalia Dewi Nawantara

Dikategorikan ABK karena siswa pada kategori ini membutuhkan pengelompokan khusus atau treatment khusus terkait kondisinya. Menindaklanjuti hal tersebut, terbentuklah kelas akselerasi atau kelas unggulan sebagai tempat yang tepat bagi siswa istimewa ini.

Terdapat beberapa karakteristik yang dimiliki oleh siswa berbakat istimewa. Karakteristik tersebut adalah yaitu tingkat Inteligence Quotient (IQ) yang tinggi, komitmen tugas (task commitment) yang baik, dan kreativitas (creativity) (Munandar, Utami., 2009). Berangkat dari karakteristik tersebut, siswa berbakat istimewa seringkali identik dengan kelebihannya di bidang akademik. Hal tersebut dikuatkan dengan pernyataan (Porter, 2005) bahwa karakteristik umum dari anak berbakat istimewa terletak pada keterampilan kognitif yang lebih unggul dibandingkan dengan individu lain.

Tidak sedikit yang beranggapan bahwa siswa dengan kemampuan high average ini diragukan keterampilan sosialnya. Anggapan keterampilan sosial yang rendah tersebut muncul karena exclusiveness mereka yang dikelompokkan dalam kelas tersendiri, berbeda dengan kelas regular pada umumnya. Hal tersebut tentu karena pertimbangan bahwa setiap anak memiliki kemampuan yang berbeda dan perlu diberikan model perilaku yang berbeda (Borland, 2005).

Penelitian terdahulu membuktikan bahwa siswa berbakat istimewa memiliki kecenderungan lebih aktif atau overexcitability apabila dibandingkan dengan siswa reguler. Hal tersebut meliputi dimensi intelektual dan imajinasi, fisik, serta emosional (Jackson et al., 2009).

Penelitian lain juga mengungkapkan bahwa siswa berbakat istimewa memiliki masalah dalam kehidupan sosialnya. Jumlah siswa yang tidak terlalu banyak dan akses sosialisasi yang cenderung kurang membuat siswa berbakat istimewa yang biasa ditempatkan pada kelas akselerasi ini menjadi terkesan anti sosial.

Beberapa studi terdahulu menyatakan bahwa siswa berbakat istimewa cenderung difokuskan untuk dapat berprestasi pada bidang akademik sehingga kekurangan waktu berkegiatan dengan lingkungan sosialnya. Selain itu siswa berbakat istimewa akan melewatkan kegiatan sosial yang penting dalam usia sebenarnya. Hal ini menyebabkan social maladjusment dan terancam mengalami kesulitan bergaul dengan teman sebaya (Jones, 2004).

Berdasarkan pemaparan diatas, maka tujuan penelitian ini adalah mengetahui profil keterampilan memecahkan konflik interpersonal siswa berbakat istimewa di SMAN Kota Malang.

\section{METODE}

Pendekatan yang digunakan dalam penelitian ini adalah pendekatan kuantitatif dengan jenis penelitian survei. Populasi penelitian ini adalah siswa akselerasi di SMAN di Kota Malang yaitu SMAN 1 Malang, SMAN 3 Malang, SMAN 4 Malang, SMAN 5 Malang, dan SMAN 8 Malang. 
Jurnal PINUS: Jurnal Penelitian Inovasi Pembelajaran, 6 (2), 2021, Rosalia Dewi Nawantara

Teknik sampling yang digunakan adalah total sampling dengan siswa berbakat istimewa sejumlah 162 siswa. Siswa yang menjadi sampel penelitian sudah memenuhi syarat siswa berbakat istimewa yaitu memenuhi tiga kriteria yaitu IQ yang tinggi, komitmen terhadap tugas yang tinggi, dan memiliki kreativitas serta masuk pada kelas khusus siswa berbakat istimewa.

Instrumen penelitian yang digunakan yaitu skala keterampilan memecahkan konflik interpersonal. Skala tersebut telah diuji validitas dan reliabilitasnya di SMAN 4 Malang di kelas XI IA 4 yang berjumlah 35 siswa. Uji validitas dan reliabilitas menggunakan bantuan SPSS 16.00 for windows menggunakan rumus korelasi product moment dengan taraf signifikansi $5 \%$. Dari hasil uji validitas tersebut didapatkan bahwa sebanyak 41 item tidak valid dan menyisakan 57 item. Walaupun demikian, setiap sub variabel masih terwakili oleh indikator. Hasil uji reliabilitas instrumen akan dijelaskan dalam tabel 1.

Tabel 1. Hasil Uji Reliabilitas

Menggunakan SPSS 16.00 for windows

\begin{tabular}{cc}
\hline \multicolumn{2}{c}{ Reliability Statistics } \\
\hline Cronbach's \\
Alpha & N of Items \\
\hline .901 & 98 \\
\hline
\end{tabular}

Uji realibilitas dilakukan dengan menggunakan SPSS 16.00 for windows dengan rumus Alpha Cronbach. Nilai Apha Cronbach yang didapatkan sebesar $0,901>0,20$ ( $\mathrm{r}$ tabel dengan $\mathrm{N}=98$ ) yang berarti skala keterampilan memecahkan konflik interpersonal reliabel.

\section{HASIL}

Hasil penelitian diuraikan dalam tabel 1 .

Tabel 1. Data Deskriptif Keterampilan

Memecahkan Konflik Interpersonal

Siswa Berbakat Istimewa

\begin{tabular}{lllll}
\hline \multicolumn{5}{c}{ Statistik Deskriptif } \\
\hline Mean & Std. & Skor & Skor \\
& Dev & min. & maks. & N \\
\hline 180,53 & 12,579 & 57 & 220 & 62
\end{tabular}

Dari tabel 1 didapatkan mean atau nilai rata-rata siswa berbakat istimewa adalah sebesar 180,53 dengan standar deviasi sebesar 2,579. Perhitungan rentang skor dihitung dari skor minimum sampai skor maksimum yaitu 57-220.

Deskripsi data keterampilan memecahkan konflik interpersonal siswa berbakat istimewa akan diuraikan dalam tabel 2.

Tabel 2 Deksripsi Data Keterampilan Memecahkan Konflik Interpersonal Siswa Program Kelas Akselerasi

\begin{tabular}{lllll}
\hline Kategori & $\begin{array}{l}\text { Rentang } \\
\text { Skor }\end{array}$ & Frek. & $\begin{array}{l}\text { Prese } \\
\text { ntase }\end{array}$ & $\begin{array}{l}\text { Klasifi } \\
\text { kasi }\end{array}$ \\
\hline $\begin{array}{l}\text { Sangat } \\
\text { Tinggi }\end{array}$ & $190-220$ & 36 & $22 \%$ & Sedikit \\
\hline Tinggi & $157-189$ & 123 & $76 \%$ & Banyak \\
\hline Cukup & $124-156$ & 3 & $2 \%$ & $\begin{array}{l}\text { Sangat } \\
\text { Sedikit }\end{array}$ \\
\hline Rendah & $91-123$ & 0 & $0 \%$ & $\begin{array}{l}\text { Sangat } \\
\text { Sedikit }\end{array}$ \\
\hline Sangat & $57-90$ & 0 & $0 \%$ & $\begin{array}{l}\text { Sangat } \\
\text { Sedikit }\end{array}$ \\
\hline Rendah & & & &
\end{tabular}

Berdasarkan tabel 2, didapatkan data bahwa keterampilan memecahkan konflik interpersonal siswa berbakat 
Jurnal PINUS: Jurnal Penelitian Inovasi Pembelajaran, 6 (2), 2021, Rosalia Dewi Nawantara

istimewa dikategorikan menjadi lima kategori. Kategori pertama adalah kategori sangat tinggi dengan rentang skor 190-220 dan frekuensi sebesar 36 siswa atau $22 \%$ yang masuk pada klasifikasi sedikit. Kategori kedua yaitu tinggi dengan rentang skor 157-189 dan frekuensi sebesar 123 siswa atau $76 \%$ yang masuk pada klasifikasi banyak. Kategori ketiga adalah kategori cukup dengan rentang skor 124-156 dan frekuensi sebesar 3 siswa atau 2\% yang masuk pada klasifikasi sangat sedikit. Kategori keempat adalah kategori rendah dengan rentang skor 91-123dan frekuensi 0 siswa atau $0 \%$ yang masuk pada klasifikasi sangat sedikit.

Data tentang tingkat keterampilan memecahkan konflik interpersonal juga akan dijelaskan pada grafik 1 .

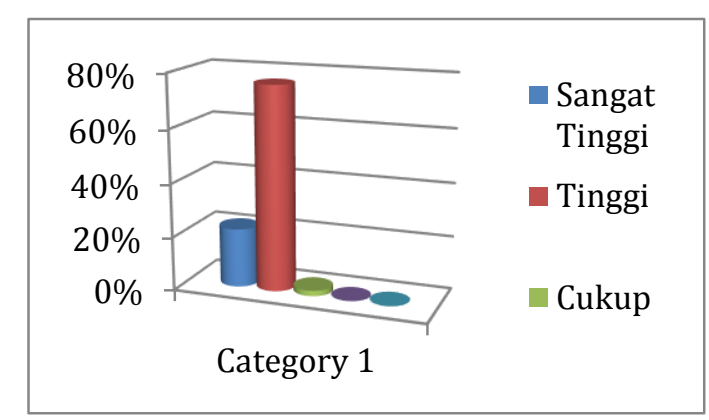

Gambar 1. Grafik Tingkat Keterampilan Memecahkan Konflik Interpersonal Siswa Berbakat Istimewa di SMAN se Kota Malang.

Dari data grafik 1. menunjukkan bahwa keterampilan memecahkan konflik interpersonal siswa berbakat istimewa mayoritas berada pada kategori tinggi.

\section{PEMBAHASAN}

Dari hasil penelitian menunjukkan bahwa keterampilan memecahkan konflik interpersonal siswa berbakat istimewa mayoritas berada pada kategori tinggi dengan skor 157-189 sebanyak 123 siswa. Data tersebut menepis anggapan bahwa siswa berbakat istimewa memiliki keterampilan memecahkan konflik interpersonal yang rendah.

Keterampilan sosial dipandang sebagai salah satu indikator kesuksesan siswa. Siswa yang memiliki ketrampilan sosial yang baik, spesifiknya dalam karakteristik interpersonal yang positif (termasuk di dalamnya keterampilan pemecahan masalah), lebih cenderung mencapai fase perkembangan yang memuaskan Sebaliknya, apabila anak tidak memiliki karakteristik interpersonal yang positif maka dapat menimbulkan masalah perilaku atau emosional dan masalah psikososial yang lain (De França-Freitas et al., 2015). Hal tersebut berlaku pada semua anak, termasuk anak berbakat istimewa.

Keterampilan sosial dijelaskan lebih lanjut sebagai pelibatan kemampuan kognitif dan non kognitif (sikap). Siswa berbakat istimewa unggul pada salah satu bidang tersebut yaitu kognitif. Kemampuan intelektual di atas rata-rata membuat siswa berbakat istimewa mahir menentukan cara untuk menyelesaikan konflik. Dalam penelitian yang dilakukan oleh (Sugiarti, Rini., Suhariadi, Fendi., 2015) diketahui bahwa kompetensi sosial siswa berbakat istimewa dipengaruhi oleh dua faktor, yaitu internal dan eksternal. 
Jurnal PINUS: Jurnal Penelitian Inovasi Pembelajaran, 6 (2), 2021, Rosalia Dewi Nawantara

Faktor internal yang memengaruhi keterampilan memecahkan konflik interpersonal siswa berbakat istimewa adalah tentang kebutuhan diri akan hubungan sosial. Siswa berbakat istimewa juga tentu memiliki kebutuhan untuk bersosialisasi sesuai kodratnya sebagai manusia. Hal tersebut yang memunculkan keinginan kuat untuk dapat berinteraksi atau menjalin hubungan sosial dengan orang lain. Tidak jarang interaksi tersebut memunculkan konflik dan membuat siswa belajar bagaimana cara untuk menyelesaikannya. Penglaman belajar tersebut kaitannya juga dengan faktor selanjutnya yaitu faktor eksternal.

Faktor eksternal yang memengaruhi keterampilan memecahkan konflik interpersonal kaitannya dengan dukungan sosial dan pengalaman yang didapatkan oleh siswa berbakat istimewa. Lingkungan yang mendorong siswa untuk semakin banyak berinteraksi dan terlibat dalam konflik didalamnya akan lebih mahir dalam memecahkan konflik interpersonal. Menurut (Clikeman, M.S., 2007) interaksi yang dilakukan pada lingkungan sosial khususnya di area tempat tinggal, hubungan dengan teman dan bahasa yang digunakan berpengaruh secara signifikan terhadap kompetensi sosial siswa. Kenyataan yang terjadi di sekolah, siswa berbakat istimewa tetap memiliki kesempatan untuk dapat bersosialisasi dengan teman sebayanya melalui kegiatan ekstrakurikuler. Iklim organisasi dalam kegiatan ekstrakurikuler juga turut membuat keterampilan memecahkan konflik interpersonal semakin terasah.
Dari pemaparan tersebut dapat disimpulkan walaupun klasifikasi siswa berbakat istimewa secara teori unggul dalam tiga bidang kehidupan yaitu kemampuan kognitif, komitmen tugas, dan kreativitas, akan tetapi apabila faktor eksternal mendukung terjadinya peningkatan kompetensi sosial maka hal tersebut tidak bisa terelakkan.

\section{SIMPULAN}

Dari Pemaparan hasil penelitian dijelaskan bahwa tingkat keterampilan memecahkan konflik interpersonal mayoritas berada pada kategori tinggi yaitu sebesar $76 \%$. Pada kategori sangat tinggi sebesar $22 \%$, kategori cukup $2 \%$, kategori rendah $0 \%$, dan kategori sangat rendah sebesar $0 \%$.

Dari data tersebut dapat disimpulkan bahwa profil keterampilan memecahkan konflik interpersonal siswa berbakat istimewa adalah tinggi atau dengan kata lain siswa berbakat istimewa juga memiliki keterampilan sosial yang sering diperdebatkan.

\section{DAFTAR RUJUKAN}

Borland, J. H. (2005). Gifted education without gifted children: The case for no conception of giftedness. In Conceptions of Giftedness: Second Edition.

https://doi.org/10.1017/CBO978051 1610455.002

Clikeman, M.S. (2007). Social Competence in Children. Springer Science and Business Media.

De França-Freitas, M. L. P., Del Prette, A., \& Del Prette, Z. A. P. (2015). Social skills of gifted and talented children. Estudos de Psicologia, 
Jurnal PINUS: Jurnal Penelitian Inovasi Pembelajaran, 6 (2), 2021, Rosalia Dewi Nawantara

19(4).

\& Kemanusiaan.

https://doi.org/10.1590/s1413-

$294 \times 2014000400006$

Jackson, P. S., Moyle, V. F., \&

Piechowski, M. M. (2009).

Emotional Life and Psychotherapy of the Gifted in Light of

Dabrowski's Theory. In

International Handbook on

Giftedness.

https://doi.org/10.1007/978-1-4020-

6162-2_20

Johnson, W. D. (2009). Reaching Out: Interpersonal Effectiveness and Actualization. Pearson Education.

Jones, T. S. (2004). Conflict resolution education: The field, the findings, and the future. Conflict Resolution Quarterly, 22(1-2). https://doi.org/10.1002/crq.100

Morton Deutsch, Peter T. Coleman, E. C. M. (2006). The Handbook of Conflict Resolution: Theory and Practice. John Wiley and Sons Inc.

Munandar,Utami.

(2009).

Pengembangan Kreativitas Anak Berbakat. Rineka Cipta.

Nawantara, R. D. (2016). Perbedaan Keterampilan Memecahkan Konflik Interpersonal Antara Siswa Kelas Akselerasi Dan Siswa Kelas Reguler Di SMAN RSBI Se-Kota Malang. Nusantara of Research: Jurnal Hasil-Hasil Penelitian Universitas Nusantara PGRI Kediri, 3(1).

Nawantara, R. D. (2017). Interpersonal Conflict Resolution Skill (Solusi Konstrukstif Bagi Konflik Interpersonal Siswa). Seminar Nasional Bimbingan Konseling Universitas Ahmad Dahlan.

Porter, L. (2005). Gifted Young Children: Meeting Their Needs. Early Childhood Australia Inc.

Sugiarti, Rini., Suhariadi, Fendi. (2015). Gambaran Kompetensi Sosial Siswa Cerdas Istimewa. Seminar Psikologi 